We must face the implications of an articulated totalitarian system of which the machine is god and must recognize that our present scientific methodology is inadequate to deal with every aspect of human experience.

\section{Social Implications of Automation}

Dr. A. Hovne, in a recent issue of Impact of Science on Society $(15$, No. 1; 1965), discusses some social implica. tions of automation, including the reasons which are likely to be decisive for the introduction of automation and why a new technique may not be adopted. After considering the unemployment aspects, he deals with the implications for four selected aspects of social life; for work in automated enterprises; for their organization; for the organization of Government. There are also certain broad choices to be made, particularly those relating to the place of work in the life of men, mobility in employment, the content of education, and to study as work. The two Cantor Lectures given to the Royal Society of Arts last March by T. R. Thompson and now published in the Journal of the Royal Society of Arts for August 1965 also deal with automation. The first of these lectures considers the economic problems of introducing automation into any process and the problem of finding the people to plan eutomation systems. The second lecture, dealing with the social consequences of automation, considers the need for anticipating its offects and the character of the new society in which automation is widely used. Besides the planning for this future, there is the problem of ensuring that the plan is feasible and also the further problem of providing the type of labour required. Finally, Mr. Thompson stresses the need to educate people to fit them for such a future and the importance of minimizing the effects of change. He suggests that a new emphasis should be placed on the real purpose of economic change; we must ensure that automation is made to serve our deepest needs, to give more leisure and to make work more interesting, so that we find greater contentment and happiness.

\section{Research in Human Genetics and Studies of Twins}

THe World Health Organization, in recognition of the increasingly important part that genetic studies are playing in the medical sciences, has established at its headquarters in Geneva a Human Genetics Unit. The purpose of the Unit is to co-ordinate and stimulate research and training in human genetics. Dr. R. L. Kirk, who is in charge of the new Unit, was formerly reader in human genetics in the University of Western Australia, where his research was concerned mainly with population genetic studies in isolated groups in south and south-east Asia, Australia and the Western Pacific. Current activities of the new Unit in Geneva include investigations of populations of unusual genetic interest, study of various hereditary conditions such as haemoglobinopathies, the setting up of facilities to service research projects, such as international reference centres for genetic markers, and improvement and standardization of methodology in genetic studies. The Unit hopes to give increasing attention to research on the distribution and public health significance of the haemoglobinopathies, including the thalassaemias and glucose-6-phosphate dehydrogenase deficioncy, as well as to stimulate interest in new methods of treatment for cases of homozygous sickle-cell disease and thalassaemia.

The use of twins in epidemiological and gonetic research is being evaluated at the present time, and the World Health Organization hopes to act in future as a clearinghouse for information on twin studies. It also hopes to play an important part in co-ordinating population genetic studies, particularly those concerned with populations still having a food-gathering or simple agricultural economy, or living as isolates in more highly developed communities. Future activities will be directed toward the role of gen tic factors in mental disorder, the standardization of techniques in studying chromosome aberrations associated with spontaneous abortion, the study of somatic cell genetics and the genetic consequences of exposure to novel chemicals in the human environment.

\section{Portraits of Tasmanian Aborigines}

Authough the aborigines of Tasmania have been extinct for some decades, a number of portraits of them are in existence which are of considerable anthropological interest. An account of them, the circumstances in which they were produced and passed into the hands of various collectors, together with their present whereabouts, has recently been published (Records of the Queen Victoria Museum, Launceston. New Series, No. 18: Thomas Bock's Portraits of the Tasmanian Aborigines. By N. J. B. Plomley. Pp. 24 (10 plates). Launceston: The Queen Victoria Museum, 1965.) The portraits are in water-colour. The originals are almost certainly the work of Thomas Bock, an engraver who was transported to Tasmania in 1824, and they were made at the roquest of G. A. Robinson, who was engaged on expeditions of conciliation with the aborigines at that time. Duplicates were also produced by Bock as well as by his son, Alfred Bock, along with other artists, mainly for Lady Franklin, wife of the Governor General. Later, many of the pictures found their way into the hands of collectors, like Dr. Joseph Barnard Davis, a surgeon living at Shelton, Staffordshire, and Richard Cull, who was secretary of the then Ethnological Society. Now, most of the portraits form part of permanent collections at the Pitt-Rivers Museum, Oxford, the British Museum, the Royal Anthropological Institute, the Fuller Collection (London), the Tasmanian Museum, and the Queen Victoria Museum, Launceston, Tasmania. Some of them were housed in the Crystal Palace, and were destroyed by the fire in 1936. The paper contains twenty reproductions of the portraits in black-and-white. On aesthetic grounds alone they are of outstanding merit; and while it is now impossible to judge of their quality as likenesses, they are impressively lifelike, constituting a record of the characteristics and facial expressions of a group of people which is compelling and unique.

\section{The Great Barrier Reef, Australia}

THE Editor has received the following communication from Dr. O. A. Jones, chairman of the Great Barrier Reef Committee, Australia: "I would like to draw the attention of your readers to the greatly expanded facilities for research on the Great Barrier Reef, Australia. The Great Barrier Reef Committee has recently spent nearly $£ 30,000$ on providing living accommodation and additional laboratory space and equipment. The facilities might be described as rather more than basic, in that they include, in addition to collecting gear and preserving materials, such items as a fume cupboard, microscopes, centrifuge, mettler balances and an incubator. There is fresh and salt water on tap, gas for laboratory heating and cooking, refrigeration (both laboratory and domestic), electric light and power, aquaria and two small boats. Seientists from anywhere in the world may live in reasonable comfort at the Station and carry out research programmes, short or lengthy, of their own choico in any of the scientific disciplines applicable to barrier reefs. The Station is admirably situated for carrying out sedimentation and beach rock studies as woll as marino biology. Heron Island Reef is about twelve square miles in area; neighbouring Wistari Reef is much larger, and there are nineteen other reefs within an area of forty square miles. The fauna of Horon and Wistari Reofs is protectod by law, but scientists may collect specimens for their research under Government permits. Additional information is obtainable from the honorary secretary, Dr. R. Endean, Department of Zoology, University of Queensland, Brisbane, Australia." 